\title{
Income Risk Management in Agriculture using Financial Support
}

\author{
Lina Novickyte $\dot{1}^{1}$
}

\begin{abstract}
Agriculture is often characterized by high variability of production outcomes, agricultural commodities prices are extremely fluctuating, and segmented agricultural markets will be influenced mainly by local supply and demand conditions, while more globally integrated markets will be significantly affected by international production dynamics. Unexpected changes in agriculture policy that affect producers' activities constitutes another important source of uncertainty to agricultural producers. Changes in regulations can have significant impact on the profitability of farming activities. Individual farms have different strategies and attitudes to manage the income risk. This article presents some theoretical insights on risks in agriculture, risk management strategies and the impact of financial support to manage risk. Government and other public stakeholders participate in risk management based on the economic benefits that farmers due to ineffective risk management and the inability of the market itself to neutralize the negative effects of the risk receive lower income. Then public stakeholders try to remedy market imperfections using various forms financial support or compensation mechanism. This strategy is often criticized, as it is impeding the functioning of free market and distorting the behaviour of farm managers in terms of risk tolerance. Therefore, the purpose of this article is to present the state-of-play in agriculture risk management and how agricultural producer's behaviour and risk tolerance affect their risk perception and the choice of different risk management strategies. The results of the review are useful in assessing the effectiveness of the current Common Agricultural Policy and considering the obtained results to draw up strategic guidelines for the future Common Agricultural Policy.
\end{abstract}

Keywords: agriculture, agricultural policy, financial support, income risk, risk perception, behaviour.

\section{Introduction}

Agriculture is characterized by severe market fluctuations that have a significant impact on farmers' incomes. Considering farm income depends on many environmental issues, technological and economic challenge well as structural changes in agricultural policies and institutions. These all multidimensional dynamics configuration creates unexpected consequences of volatile income flows during the whole agriculture value chain (Darnhofer et al., 2016). In this context, farmers must apply strategies and instruments to manage their income and risks and to achieve income stability (Hardaker et al., 2015). The risk-reducing associated with income which will improve farmers' wellbeing and their competitiveness and the ability to expand its activities through innovation and relevant investment decisions (EP, 2014).

Given the importance of good risk management policy-makers, and agricultural experts seek to understand the farmers' decision regarding the possible risk management strategies. In addition, agricultural policy-makers are increasingly struggling to liberalize the agricultural market and price formation, accordingly changing market regulation policies 
(such as intervention prices, export subsidies and production quotas) into sectoral risk management measures (such as direct payments and insurance schemes). However, the government and other public stakeholders actively participated in creating risk management strategy in agriculture. That strategy is often criticized because it is impeding the functioning of the free market and thus distorting the behaviour of farm managers in terms of risk tolerance. Therefore, it is important to assess the various risk management strategies, and, those where the government is involved, in terms of their cost-effectiveness and their impact on agriculture producer's decisions. Attention must be paid to farmer's behaviour when in the market are various risk management strategies (especially based on state financial support) and if such strategies do not exist. It is important to identify how agriculture producer's behaviour changes when making economic management decisions based on risk in the context of different risk management strategies. To better fit the agricultural policy, the policy-makers also need to have a better understanding of farmers' intentions to apply different risk management strategies.

Some authors (Hardaker et al. 2015, Ratas and Nurmet 2017, Huirne et al. 2000, Musser and Patrick 2002, Kimura et al. 2010, Girdžiūtè 2013, OECD 2000, 2009, 2011, van Asseldonk et al. 2016, van Winsen et al. 2016) present a comprehensive view on risks in agriculture and different strategies to manage these risks. Other authors (Marra et al. 2003, Emery and Franks 2012, Bocquého, et al. 2014, Emery 2015, Prager 2015, Barham et al. 2018, Pivoto et al. 2018) made some interesting studies on how farmer's behaviour influenced the decision-making process and risk perception.

The purpose of this article is to present the state-of-play in agriculture risk management and how agricultural producer's behaviour and risk tolerance affect their risk perception and the choice of different risk management strategies.

The paper proceeds as follows. In the next section, outline findings from several past literature reviews on risk in agriculture and risk management strategies. Also, there is presented some additional insight in the light of behavioural economics impact to select an appropriate risk management strategy. The last but not least part of this section focuses on the challenges to the new Common Agriculture Policy for period 2021-2027. The final section provides some concluding remarks.

\section{Risk in Agriculture and the Behavioural Aspect in Risk Management}

Agriculture is a risky business because it is exposed to various external and internal conditions. Farmers are confronted with various risk from different sources (see Fig. 1): from production risk to market risk, and from financial risk to institutional risk. Kimura et al. (2010) distinguished the two main source of risk which faced the farmers: production and prices. The production variability mainly influenced due to changes in weather conditions and prices mainly due to market changes. Hardaker et al. (2015), Ratas and Nurmet (2017), Huirne et al. (2000), Musser and Patrick (2002) define one more group of risk in agriculture - human resources or personal risk. This risk related to uncertain life events (e.g. illness, divorce, etc.) or possibility that family or employees will not be able to work in a farm. OECD $(2000,2009)$ adds an ecological risk, but this risk closely linked to production, climate change risks; there is a certain interconnection between production and ecological risk. Also, Ratas and Nurmet (2017) based on the theoretical research noticed, 
that risk can be categorized into external and internal, where external risk includes price and institutional risks and internal risk includes production, financial, and personal risks. Girdžiūtė (2013) proposed all risks divide to controlled and uncontrolled risks based on farmers' possibility to control risk source (the production and financial risks are classified to the controlled risks, and to uncontrolled - market and institutional).

The income risk can be as a part of production risk, on the one hand, because it depends on the decisions of the farmer, and on the other hand, can be attributed to the market or price risk, because farmer operates under market conditions and the market has the direct influence on income risk. One of the factors influenced the income risk is the changes in prices on agricultural products' markets and production factors. Farm income volatility depends on prices, yields, costs, price, and support variability, but also depends on the interconnection of all these elements and the diversification of production. Fig. 2 presents the commodity, agriculture, and food price indexes, and volatility of agriculture prices. It shows, that during 2010-2018 prices of agriculture commodities have big fluctuations and since 2014 there is a significant drop in prices, which negatively affected the farm income.

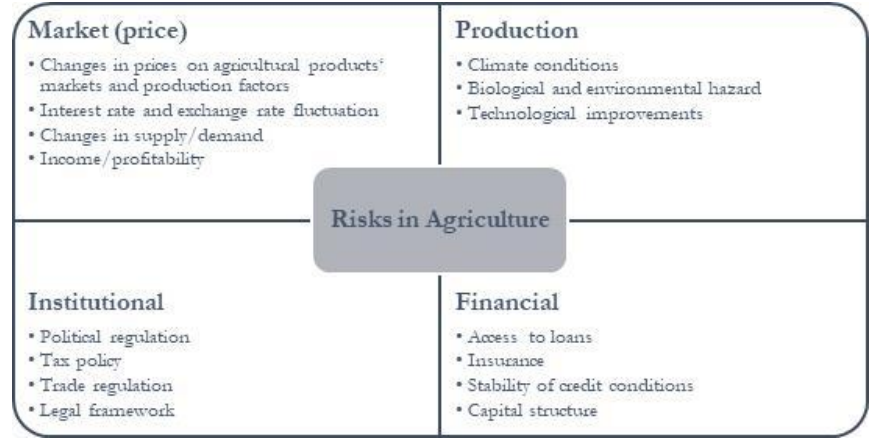

Fig. 1 Risks in Agriculture

Source: Girdæ̌iūé (2013), Hardaker et al. (2015), Ratas and Nurmet (2017), OECD (2000, 2009).
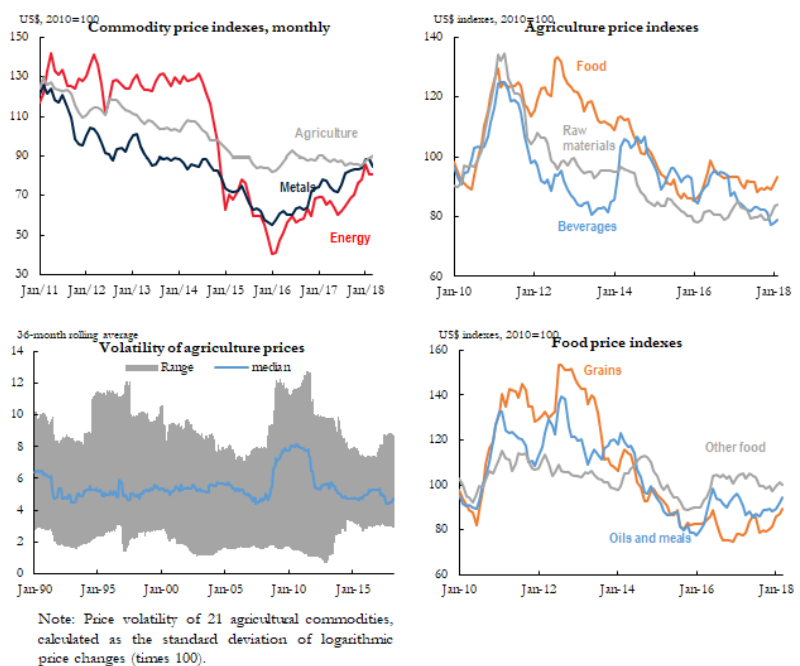

Fig 2. Commodity, agriculture, and food price indexes, monthly; volatility of agriculture prices

Source: World Bank, Commodity Markets (2018)

Another important factor which has influence especially the future income volatility will be climate change. According to the Global temperature report for 2017 (2018), 2017 
was the second warmest year on Earth since 1850. In future, these changes can play a significant role in affecting the farm's income. One of the main challenges is the Paris Agreement on Climate Change, where countries must keep global temperature rise well below $2{ }^{\circ} \mathrm{C}$ and encourages parties to strive for the warming of no more than $1.5^{\circ} \mathrm{C}$. The global warming makes irreversible changes in agriculture which affected the future farm's income. Based on the main global and EU challenges the policy-makers should pay more attention to realised more cohesive policy which helps to better adapt to the negative impact of climate changes. The farmers must change their understanding of the effects of climate on their activities and invest in the new technologies that allow them to adapt properly to climate change. One of the solutions would be to use precision farming to sustainably develop its activities and ensure stable income in the future. Antón et al. (2012) argued that there is a close link between adaptation and risk management policies, and governments' responses for protecting farmers against the risks of climate change will affect their strategies. They pay attention, that state support for insurance schemes and ex-post payments can reduce the incentive to diversify farm output from more climate-sensitive crops and farms practices.

Table 1 and Fig. 3 presents the real income per AWU trend in the EU, euro area, and in two countries: Lithuania and Italy. Agricultural factor and family farm income per AWU indicator characterized by high volatility in Italy and Lithuania, especially the big fluctuation is in family farm income (StDev of indicator respectively 21.0 and 28.1). Noted that in 2016 the level of family farm indicator in Lithuania and in Italy was below the average of the previous 5 years (respectively $33.3 \%$ and $3.3 \%$ ). The real factor income has a similar income fluctuation as it is in the family farms (StDev of an indicator in Italy is 9.78 and in Lithuania - 13.3).

Juvančič and Cahil (2017) noted, that nowadays the EU agriculture is affecting by markets, production risks, and regulatory uncertainty. All these factors have a combined effect on income from farming. They proposed that the EC must in coherent and holistic view integrating the risk management instruments into the whole CAP. Also, is needed to pay more attention to farmers' behaviour to minimize the existing biases, thus ensuring the proper application of risk management tools.

Table 1. The factor and family farm income during 2010-2017, million euro (values at current prices)

\begin{tabular}{lcccccc}
\hline & $\mathbf{2 0 1 0}$ & $\mathbf{2 0 1 4}$ & $\mathbf{2 0 1 6}$ & $\mathbf{2 0 1 7}$ & $\begin{array}{c}\text { Growth, 2010- } \\
\text { 2017 }\end{array}$ & Average \\
\hline $\begin{array}{l}\text { EU (current composition); } \\
\text { factor income }\end{array}$ & 143127.34 & 159358.63 & 153936.80 & 169318.32 & $18.30 \%$ & 155522.46 \\
\hline $\begin{array}{l}\text { Euro area (19 countries); } \\
\text { factor income }\end{array}$ & 109286.18 & 117926.19 & 114716.47 & 126166.83 & $15.45 \%$ & 115949.90 \\
\hline Italy; factor income & 17258.99 & 23275.68 & 23153.83 & 24154.44 & $39.95 \%$ & 22168.36 \\
\hline Lithuania; factor income & 613.20 & 934.77 & 858.51 & 1058.54 & $72.63 \%$ & 922.21 \\
\hline $\begin{array}{l}\text { EU (current composition); } \\
\text { entrepreneurial income }\end{array}$ & 86687.19 & 100521.47 & 93236.80 & 107840.27 & $24.40 \%$ & 97028.54 \\
\hline $\begin{array}{l}\text { Euro area (19 countries); } \\
\text { entrepreneurial income }\end{array}$ & 66018.49 & 71747.87 & 66936.98 & 77399.85 & $17.24 \%$ & 70034.21 \\
\hline $\begin{array}{l}\text { Italy; entrepreneurial income } \\
\text { Lithuania; entrepreneurial }\end{array}$ & 8179.99 & 13742.91 & 13215.51 & 14006.54 & $71.23 \%$ & 12617.35 \\
\hline income & 329.60 & 576.49 & 432.51 & 597.04 & $81.14 \%$ & 564.40 \\
\hline \begin{tabular}{l} 
Source: \\
\hline
\end{tabular}
\end{tabular}

Source: Eurostat (2018), aact_eaa01 
Index of the real income of factors in agriculture per annual work unit, $2010=100$

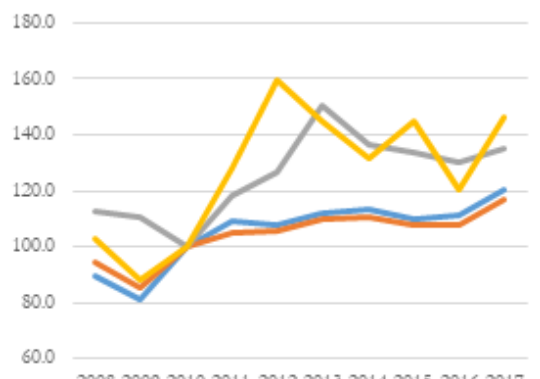

2008200920102011201220132014201520162017

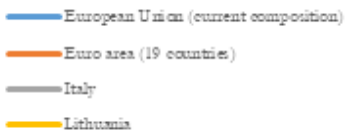

Index of real net agricultural entrepreneurial income, per unpaid annual work unit, $2010=100$

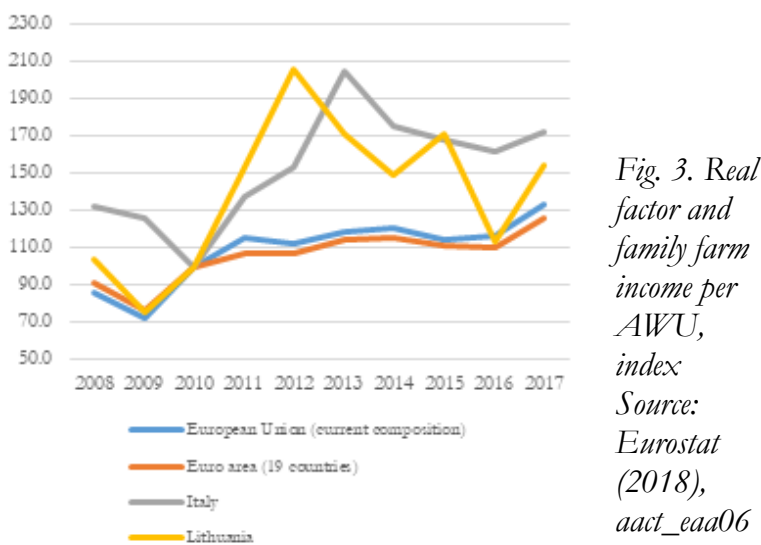

To better adapt to a negative impact of price volatility and other negative factors which increase the income fluctuations is needed to pay attention to effective risk management strategies in agriculture. In literature (Hardaker et al. 2015, Ratas and Nurmet 2017, OECD 2000, 2009, 2011) is presented a set of risk management strategies based on risk attitude and risk perception between two extremes - to avoid risk or to accept the risk. Hardaker et al. (2015) assigned risk management strategies in agriculture to two groups: to the first group belongs on-farm risk-management strategies, which are between risk avoidance and risk reduction, e.g. information collecting to effectively manage risk and make the informed decisions, selecting less risky technologies, diversification, flexibility (asset, product, market, cost, and time); the other group consists the risk-sharing strategies, such as different sources of business financing, insurance, share contracts, and trading in commodity derivatives. All these strategies have pros and cons and considering the level of risk tolerance of the farmer, one or several combinations may be used.

Van Asseldonk et al. (2016) argued, that European farmers may choose from three general types of risk management strategies: on-farm (e.g. diversification), price risk transfer (e.g. contracts) and yield risk transfer (i.e. insurance with or without public assistance). And based on the research results, they noticed, that risk management strategies differ across the Member States. Farmers decisions on the approval of risk management strategies depend on related costs (e.g. insurance premiums) relative to the benefits that can be grasped in risk mitigation (e.g. compensation in adverse years).

Van Winsen et al. (2016) found out that risk management in farms is not so much focused on the risks that faced, but rather on the attitude towards risk. Risk-averse farmers are more prone to passive risk management, rather than addressing individual risks, but farmers who are more willing to take risks are managing risk with a proactive attitude. Also, these both farmers groups select the different instruments to manage the risk. Another important finding is that proactive risk management strategies allow the farmer to adopt an entrepreneurial approach to farm management.

Another important strategy to manage risk is correlation between the variables or components of the farm income; if there is negative correlation one variability partly compensates for another variability, and if all farm incomes include multiple sources, it is sufficient that they do not show any better co-movements that could lead to a reduction 
in overall income volatility. Diversification in production and output-cost covariance play a significant role in reducing farm income risk. Kimura et al. (2010) also noticed that farmers can potentially benefit from negative price-yield and revenue-costs correlations, and from an imperfect correlation of returns from different sources such as different productions and different activities including off-farm. The World Bank (Thinking CAP... 2017) researcher also agreed that diversification of income is an important risk mitigation strategy for the rural farm households. And farmers, which can better diversify their income, can better mitigate risks and shocks.

Another important tool used in risk management is government participation based on the economic benefits that farmers who are exposed by risk receive lower income due to ineffective risk management and the inability of the market itself to neutralize the negative effects of the risk. Then government tries to remedy market imperfections using various forms of financial support or compensation mechanism. However, as noted by Kimura et al. (2010) each farmer has much better information on the nature of their risk environment than governments. This situation is caused by information asymmetry. And policy-maker should pay attention to how to empower farmers to take their own risk management decisions and to have access to a variety of instruments and strategies.

All direct payments to farmers have an impact on risk management. However, there is evidence that highly decoupled payments, such as the SFP in the EU, have a very limited impact on other risk management strategies and have a very limited impact on income fluctuations. Because of the higher efficiency of the transfer of income, they are relatively more effective in improving the welfare of farmers than other government programs. They are also effective in increasing the minimum income of each farmer, although they do not apply to low-income farmers (Kimura et al. 2010). With this point of view agree and the World Bank researchers (Thinking CAP... 2017), they argued that the CAP Pillar I payments better deal with risk in poorer farmers, while such kind of subsidies on rationale and more successful farmers is weaker, because they can use a private solution to reduce risk (e.g. insurance, diversification). According to the EU report on state aid (State of Play of ... 2016), during the 2007-2013 CAP instruments to manage risks have not been very successful. During the 2014-2020 the CAP support to agricultural risk management has increased, but the share of CAP spending on CPM measures remains very low (less than $2 \%$ of Pillar II and $0.4 \%$ of the total 2014-2020 CAP budget) (State of Play of ... 2016). The new EC report "Modernising and simplifying the CAP: Economic challenges facing EU agriculture" (2017) provides a lot of economic challenges facing agriculture and rural areas at present and will have a significant impact on the future. One of the challenges is tied to pressures on farm income. This is related to low income in this sector, income fluctuations, which in the future may be affected due increasing by climate change and trade openness, which has a strong impact to price fluctuation. In this report (Modernising and ... 2017) there are presented some important market uncertainties which have a significant impact on future sustainable farms income:

- High price volatility.

- Lower price levels.

- Growth of total costs of production.

- Falling of gross fixed capital formation. 
- Climate change.

- Investment gap: a fall in public investments in agriculture R\&D.

- A lack of market transparency.

- Primary sector fragmentation.

- Uneven price transmission along the supply chain.

- A lack of vertical integration initiated by primary sector.

Another important factor, which has a significant impact on the successful implementation of the nowadays and future CAP policy which can significantly contribute to proper risk management is behavioural biases. Behavioural biases can have a negative impact on the successful implementation of the CAP. As Kahneman and Tversky (1979) argued in their well-known publication "Prospect Theory: An Analysis of Decision under Risk" and in the revised version of this research (Kahneman and Tversky, 1992), the people make the decisions based on 4 principles. People do not like uncertainty and always prefer certainty, so they tend to give up part of their income for the sake of clarity. People are more likely to give greater importance to losses than gains. When a person suffers a loss, he/she is likely to risk further, with the aim of eliminating the negative result and he/she will not accept the loss. Decision makers are more likely to be interested in relative earnings and losses than final revenues and benefits. If the relative position does not improve, the person does not feel better, even though his income may have increased significantly. People tend to underestimate events that are less likely to occur. For example, a person may not fully consider an event that would eventually lose all his income if the probability of occurrence of this incident is very low. This explains the fact why many individuals tend to make risky decisions. A person will usually focus only on events that are very likely to occur. According to this theory, the authors in their paper "Judgment under Uncertainty: Heuristics and Biases" (1974) distinguished and described three major heuristics and biases: representativeness, availability, and adjustment and anchoring. The authors pointed out that many decisions are based on beliefs about the likelihood of unclear events. Based on these findings, the EC in the report (Modernising and ... 2017) also argued, that farmers make the decisions to invest in new profit-enhancing technology affected by different behavioural factors. The farmers are also influenced by the market uncertainty, loss aversion, risk aversion, behavioural control, and option values biases. The other biases, like a lack of trust, lack of leadership, individual farm identity, and individualism negatively affected farmers to engage in joint initiatives such as POs, mutual, income stabilisation tool. All these biases make a negative impact on the future farmers' decisions to invest in the new technologies, select appropriate risk management measures, and probably to seek higher revenues. The farmers, as the decision-makers make a significant contribution to the productivity growth, and income distribution of an economy.

Bocquého, et al. (2014) also noticed that farmers are characterised by a concave utility function for gain outcomes implying risk aversion and they are twice as sensitive to losses as to gains and tend to pay undue attention to unlikely extreme outcomes. Barham et al. (2018) found that the earliest adopters of the new technology or progressive farmers are those who have both high cognitive ability and have a low receptiveness to advice. Pivoto et al. (2018) noticed, that adapt to a smart technology in agriculture is hindered by the lack of education, ability, and skills of farmers to understand and handle 
a smart technology. Emery (2015) analysed British farmers' cooperation and independence and found that independence is most often conflated with individualistic premises. The author argued, that this situation leads farmers to see their neighbours as natural competitors: as those from whom which independence must be sought. Emery and Franks (2012) analysed the receptivity of farmers to the idea of landscape-scale, collaborative agri-environment schemes in England areas. They found that a lack of communication and mutual understanding between farmers, a cultural imperative for independence and timeliness, and alternative interpretations of risk amongst farmers present potential barriers to participate in agri-environment schemes. Prager (2015) offers some possibilities to improve collaboration between farmers and other stakeholders. She argued that national specifications created the necessary space for addressing local issues and that countries offered additional regional or local systems that would be more conducive to support existing co-workers. She added, that national specifications can create the necessary space to accommodate local issues and that countries offer additional regional or local schemes that are more conducive to support existing co-operation. Also, is it important to find a balance between the collective actions and the scale at which support for these actions are designed, implemented and evaluated. Marra et al. (2003) analysed what role plays risk, uncertainty, and learning in the process of adopting new technologies, especially agricultural technologies. The findings support that a new technology adoption processes are strongly affected by riskrelated issues. The authors distinguished, that the agriculture producers make the decisions having regard to its perceptions about the riskiness of a technology, its attitudes to risk, the role of trialling and learning in adoption decisions, and the option value of delaying adoption.

Policy-makers should pay attention to it because farmer's individualistic attitude and a competitive advantage over their neighbours can destroy the various forms of farmers' co-operation proposed by politicians to manage risks. In this context, policy-makers must prove to the agriculture producers that cooperation is achieved more benefits than losses. Relative positioning and individualism biases can negatively affect farmers to connect to mutual funds etc.

A holistic approach to risk management in agriculture, which is highlighted by the OECD (2009), is needed to strengthen cooperation between different stakeholders and to use more effective risk management schemes. Different government policies and programs can help directly reduce the risk (e.g. price intervention) or indirectly through supported market mechanisms (e.g. insurance subsidies). If there are any risks which in any case involve government programs, incentives to use other risk management strategies (e.g. insurance or diversification) are reduced. A good understanding of the net effect of government policies on risk management in agriculture necessarily involves analysing the interaction between different sources of risk, different farmers' strategies and government programs (Kimura et al. 2010).

Another important aspect of how public stakeholders are ready to contribute to the establishment of an effective risk management system is the new CAP which will be active for 2021-2027. Based on the CAP objectives has undergone a series of reforms, and now in the light of the new 2021-2027 budget proposal, the European Commission and the Member States must find the new way to effectively implement these objectives. 
During the next EU budget for the 2021-2027 period, the Commission proposes to modernize and simplify the CAP. Although the CAP budget is being reduced by $5 \%$, however a budget of $€ 365$ billion has been set aside to ensure that the CAP continues to be a viable policy that will continue to support farmers and rural communities, develop the EU agriculture sustainably and take the EU environmental and climate policy objectives into account (see Fig. 4). The new budget opens the ways to the Member States with additional flexibility and responsibility to choose how and where to invest the funds of the CAP to reach the EU level to identify the significant progress-resistant, sustainable and competitive agricultural sector objectives, while at the same time ensuring a fair and targeted income support for farmers. The CAP budget will be divided into two traditional pillars: direct payments (annual payments to farmers to help stabilize farm incomes due to volatile market prices and weather conditions) and market measures (addressing specific market situations and supporting trade promotion). The second pillar relates to rural development policy and seeks to ensure balanced territorial development and the maintenance of the green agricultural sector and the promotion of competitiveness and innovation. The CAP budget represents an average of $28.5 \%$ of the total EU budget of the 2021-2027 period. The major part of the CAP budget (€265.2 billion, $\sim 73 \%$ ) will be earmarked for direct payments, $€ 20$ billion for market support measures (EAGF), and $€ 78.8$ billion for rural development (EAFRD). An additional $€ 10$ billion will be allocated under the EU Research Framework "Europe Horizon" for specific studies on the food industry, agriculture, rural development and bio-economy.

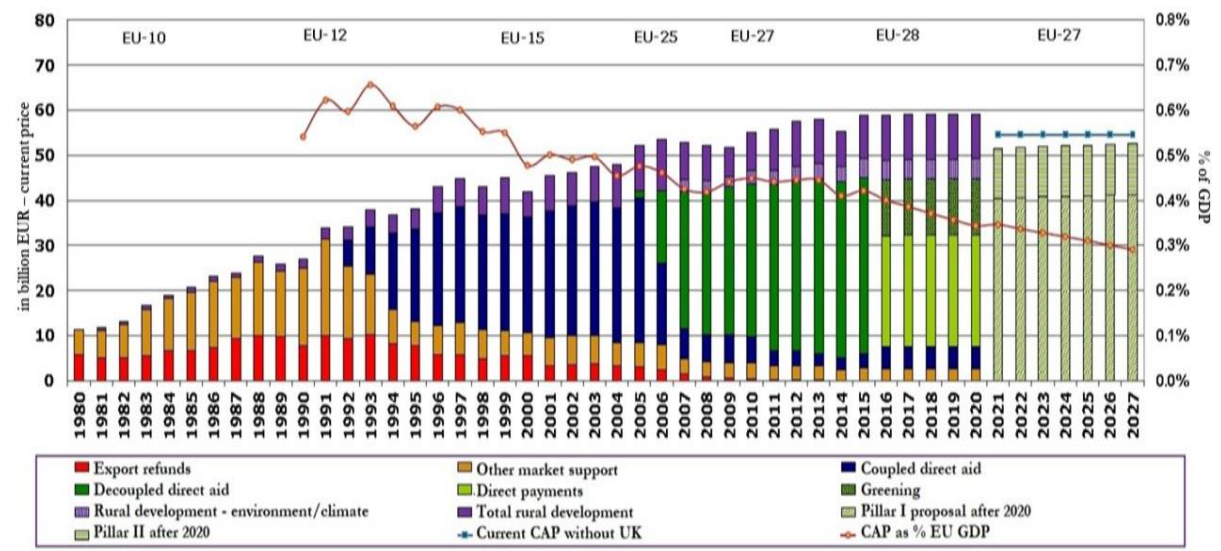

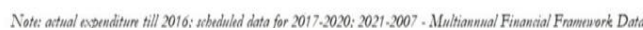

Fig. 4. CAP expenditure and CAP reform path Source: EC (2018)

Having regard to the CAP budget proposal, the European Commission presents the renewed objectives of the future CAP. The new proposal includes 9 goals to seek sustainable development of the EU agriculture. One of the goals related to ensuring farm income. There is also an integrated goal of promoting knowledge, innovation and the digitization of the agricultural sector and rural areas which can help farmers better adapt to new technologies, used precision farming to better react for the future challenges, especially which have the significant impact to income volatility.

According to the new CAP, further improvements have been made. The EC ensures that 
member-states will have to support risk management measures under rural development programs to help farmers manage production and income risks that they cannot control. Also, member-states will be mandatory to provide this kind of support that will be given as financial assistance to pay premiums for insurance and mutual funds, to protect against the risks associated with both production and income. It becomes mandatory under the rural development programs to support a variety of actions, such as investment and training, helping farmers to prevent the risk or eliminate its negative consequences. An EU-level risk management platform will be set up - a common reference centre for many stakeholders to facilitate the sharing of knowledge and the exchange of experience between farmers, public authorities, research institutions, the private sector, etc. There will also be financial instruments available to assist in obtaining working capital, for example, to help farmers to overcome a temporary lack of liquidity due to unexpected crises. As the EC ensures, that "Horizon 2020" will fund research on risk management, agricultural digitization and intelligent use of large-scale data in agriculture and will also be able to support risk management projects through the European Innovation Partnership. These improvements in risk management can be vital to better mitigate risks and shocks.

All these changes in the new CAP can actively contribute creating a successful risk management strategy in agriculture. However, is needed to pay attention to one significant factor that may be adversely affect proposed innovation - the farmers behavioural and their risk perception. To eliminate this factor, it should be noted the OECD proposed a holistic approach to shaping the risk management strategy.

\section{Conclusions}

In this study, there is presented a state-of-play in agriculture risk management and how agricultural producer's behaviour and risk tolerance affect their risk perception and the choice of different risk management strategies. The analysis shoved, that farmers are confronted with various risk from different sources: from production risk to market risk, and from financial risk to institutional risk. Farm income volatility basically depends on prices, yields, costs, price, and support variability, and on the interconnection of all these elements and the diversification of production. Another important factor which has influence especially the future income volatility will be climate change and trade openness, which make a pressure on price fluctuation. On the other hand, the protectionist policies that are currently being implemented in some countries can be transposed into the agricultural sector and in the future also will have a significant impact on farm income fluctuations.

In additional to manage risks in agriculture, there is presented a set of risk management strategies based on risk attitude and risk perception between two extremes - to avoid risk or to accept the risk. All risk management strategies in agriculture can be divided into two groups: on-farm risk-management strategies, and the risk-sharing strategies. Another important strategy to manage risk is a correlation between the variables or components of the farm income. It should also be kept in mind another important tool used in risk management, especially in income risk - government participation and it proposes tools to absorb the market imperfections using various forms of financial support or 
compensation mechanism.

Based on the behavioural aspect in farmer's decision-making process the policy-makers should pay attention to it because farmer's individualistic attitude to risk perception can negatively affect the successful implementation of different risk management strategies. Only a holistic approach to risk management in agriculture, which is highlighted by the OECD and the strongest cooperation between different stakeholders can add value to use more effective risk management schemes in agriculture.

Finally, future studies can be linked to the value and impact of the behavioural biases adapt to different risk management strategies based on the holistic approach. Empirical studies should be targeted to the environmental and technical challenges which impact in future will be one of the biggest on the farm's income volatility.

\section{Acknowledgments}

This research was funded by the European Social Fund under the No 09.3.3LMT-K-712 "Development of Competences of Scientists, other Researchers and Students through Practical Research Activities".

\section{Conflicts of Interest}

The author declares no conflict of interest. The funder had no role in the design of the study; in the collection, analyses, or interpretation of data; in the writing of the manuscript, and in the decision to publish the results.

\section{References}

Antón, J., Kimura, S., Lankoski, J., and Cattaneo, A. (2012). A Comparative Study of Risk Management in Agriculture under Climate Change, OECD Food, Agriculture and Fisheries Working Papers, No. 58, OECD Publishing. http://dx.doi.org/10.1787/5k94d6fx5bd8-en

Barham, B., L., Chavas, J-P., Fitz, D., and Schechter, L. (2018). Receptiveness to advice, cognitive ability, and technology adoption, Journal of Economic Behavior and Organization, 149: 239-268. https://doi.org/10.1016/j.jebo.2017.12.025

Bocquého, G., Jacquet, F., and Reynaud, A. (2014). Expected utility or prospect theory maximisers? Assessing farmers' risk behaviour from field-experiment data, European Review of Agricultural Economics 41(1): 135-172. doi:10.1093/erae/jbt006

Commodity Markets (2018). The World Bank, Washington, 10 June 2018. Retrieved from: http://www.worldbank.org/en/research/commodity-markets

Darnhofer, I., Lamine, C., Strauss, A., and Navarrete, M. (2016). The resilience of family farms: towards a relational perspective. Journal of Rural Studies 44: 111-122. https://doi.org/10.1016/j.jrurstud.2016.01.013

EC (2018). Bendros žemés ükio politikos modernizavimas ir supaprastinimas: tikslingumas, lankstumas ir veiksmingumas. Presentation at the Debate on a Common Agricultural Policy for the EU after 2020, Vilnius, Lithuania.

Emery, S., B. (2015). Independence and individualism: conflated values in farmer cooperation?, Agriculture and Human Values, 32: 47-61. doi: 10.1007/s10460-014-9520-8

Emery, S., B. and Franks, J., R. (2012). The potential for collaborative agri-environment schemes in England: Can a well-designed collaborative approach address farmers' concerns with current schemes?, Journal of Rural Studies, 28: 218-231. doi:10.1016/j.jrurstud.2012.02.004

EP (2014). Comparative analysis of risk management strategies supported by the 2014 Farm Bill and the CAP 2014-2020. Brussel: European Parliament.

EU Budget: The Common Agricultural Policy beyond 2020. (2018). European Commission - Fact Sheet, Brussels, 1 June 2018. Retrieve from: http://europa.eu/rapid/press-release_MEMO-18-3974_en.htm 
Eurostat (2018). Database of economics accounts for agriculture. Retrieved from: http://ec.europa.eu/eurostat/data/database?p_P_id=NavTreeportletprod_WAR_NavTreeportletprod_INSTANCE_nPqeVb PXRmWQ\&P_P_lifecycle=0\&p_P_state=normal\&p_P_mode $=$ view\&P_P_col_id $=$ column2\&p_P_col_pos $=1$ \&\&_P_P_col_count $=2$

Girdžiūtè, L. (2013). Integruotas rizịkos žemès ükyje vertinimas. Daktaro disertacija.

Global Temperature Report for 2017 (2018). Retrieved from: http://berkeleyearth.org/global-temperatures-2017/

Hardaker, J., B., Lien, G., Huirne, R., B., M., and Anderson, J., R. (2015). Coping with Risk in Agriculture. (3nd edition). Wallingford: CABI Publishing. https://doi.org/10.1079/9780851998312.0000

Huirne, R., B., M., Meuwissen, M., P., M., Hardacker, J., B., and Anderson, J., R. (2000). Risk and risk management in agriculture: an overview and empirical results, International Journal of Risk. Assessment and Management, 1: 125-136.

Juvančič, L., and Cahill, C. (2017). Risk management in EU agriculture. Retrieved from: https://ec.europa.eu/agriculture/sites/agriculture/files/events/2017/cap-have-your-say/170704-juvancic.pdf

Kahneman, D., Tversky, A. (1979). Prospect theory: an analysis of decision under risk, Econometrica 47(2): 263-292.

Kahneman, D., Tversky, A. (1992). Advances in prospect theory: cumulative representation of uncertainty, Journal of Risk and Uncertainty 5(4): 297-323.

Kimura, S., Antón, J., and C. LeThi (2010). Farm Level Analysis of Risk and Risk Management Strategies and Policies: Cross Country Analysis, OECD Food, Agriculture and Fisheries Papers, No. 26, OECD Publishing, Paris. http://dx.doi.org/10.1787/5kmd6b5rl5kd-en

Marra, M., Pannellb, D., J., and Ghadimb, A. A. (2003). The economics of risk, uncertainty and learning in the adoption of new agricultural technologies: where are we on the learning curve?, Agricultural Systems 75: 215-234.

Modernising and Simplifying the CAP: Economic challenges facing EU agriculture (2017). The European Commission. Directorate-General for Agriculture and Rural Development. 42 p.

Musser, W., N., and Patrick, G., F. (2002). How Much does Risk Really Matter to Farmers?. In: Just R.E., Pope R.D. (eds) A Comprehensive Assessment of the Role of Risk in U.S. Agriculture. Natural Resource Management and Policy, vol 23. Springer, Boston, MA. pp. 537-556. https://doi.org/10.1007/978-1-4757-3583-3_24

OECD (2000). Income Risk. Management in Agriculture. Paris, 147 p. https://doi.org/10.1787/9789264189584-en

OECD (2009). Managing Risk in Agriculture: A Holistic Approach. Paris. 172 p. http://dx.doi.org/10.1787/9789264075313-en

OECD (2011). Managing Risk in Agriculture: Policy Assessment and Design. Paris, 257 p. http://dx.doi.org/10.1787/9789264116146-en

Pivoto, D., Waquil, P., D., Talamini, E., Spanhol Finocchio, C., P., Dalla Corte, V., C., and de Vargas Mores, G. (2018). Scientific development of smart farming technologies and their application in Brazil, Information Processing in Agriculture, 5: 21-32. https://doi.org/10.1016/j.inpa.2017.12.002

Prager, K. (2015). Agri-environmental collaboratives for landscape management in Europe, Current Opinion in Environmental Sustainability, 12: 59-66. http://dx.doi.org/10.1016/j.cosust.2014.10.009

Ratas, M. and Nurmet, M. (2017). Risk management practices of agricultural enterprises - evidence from Estonia. Risk in the food economy - theory and practice, ed. J. Góral, M. Wigier. Warsaw: Institute of Agricultural and Food Economics, p. 41-52.

State of Play of Risk Management Tools Implemented by Member States during the Period 2014-2020: National and European Framework - Research for AGRI Committee (2016). Brussels: Directorate-General for Internal Policies Policy Department B: Structural and Cohesion Policies, 146 p. doi: 10.2861/305797

Tversky, A., Kahneman, D. (1974). Judgment under uncertainty: heuristics and biases, Science, New Series 185(4157): 1124-1131.

van Asseldonk, M., Tzouramani, T., Ge, L., and Vrolijk, H. (2016). Adoption of risk management strategies in European agriculture, Studies in Agricultural Economics 118: 154-162. http://dx.doi.org/10.7896/j.1629

van Winsen, F., de Mey, Y., Lauwers, L., van Passel, S., Vancauteren, M., and Wauters, E. (2016) Determinants of risk behaviour: effects of perceived risks and risk attitude on farmer's adoption of risk management strategies, Journal of Risk Research, 19(1): 56-78, DOI: 10.1080/13669877.2014.940597

World Bank (2017). Thinking CAP: supporting agricultural jobs and incomes in the EU. Washington, 68 p. 